\title{
Comparison of diets based on grass silage, hay or oat straw supplemented with four levels of concentrates in the feeding of growing Ayrshire bulls
}

\author{
Ilmo Aronen, Martti Lampila and Helena HePola
}

\begin{abstract}
Aronen, I. ', Lampila, M. ${ }^{1}$ \& Hepola, $\mathrm{H}^{2}{ }^{2}$ 1994. Comparison of diets based on grass silage, hay or oat straw supplemented with four levels of concentrates in the feeding of growing Ayrshire bulls. Agricultural Science in Finland 3: 15-26. ('Agricultural Research Centre of Finland, Institute of Animal Production, FIN-31600 Jokioinen, Finland and ${ }^{2}$ Department of Animal Science, P.O. Box 28, FIN-00014 University of Helsinki, Finland. Present address: Ilmo Aronen, Rehuraisio Ltd, P.O. Box 101, FIN-21201 Raisio, Finland.)
\end{abstract}

This experiment was conducted during three consecutive years with 144 Ayrshire bulls of an initial age of 185 days and live weight of $186 \mathrm{~kg}$. The experimental period lasted for 224 days. The ad libitum fed roughages were grass silage, hay and oat straw, each supplemented with four levels of concentrates, the number of treatments thus being 12 . Daily supplements of concentrates were $0,1,2$ or $3 \mathrm{~kg}$ on grass silage feeding, 1, 2, 3 or $4 \mathrm{~kg}$ on hay feeding and 2, 3, 4 or $5 \mathrm{~kg}$ on straw feeding. Barley was used as a concentrate on grass silage feeding, but part of it was replaced by rapeseed meal and urea in the hay and straw feeding groups to balance the nitrogen intake.

An increase in concentrate intake was found to decrease the roughage intake with each type of roughage, but the total intake of dry matter (DM) was increased. Increasing the level of concentrates enhanced both the rate of daily live weight gain (LWG) and carcass gain. However, $2 \mathrm{~kg}$ more concentrates was needed on hay feeding than on grass silage feeding to obtain similar carcass gain. On straw feeding, $4 \mathrm{~kg}$ of concentrates was not sufficient to obtain a comparable carcass gain as with grass silage alone. The response to concentrate supplementation on grass silage feeding indicated, however, that the growth potential of the bulls receiving silage alone or silage with small amounts ( 1 or $2 \mathrm{~kg} /$ day) of concentrates was not completely utilized.

The study showed that LWG is an inadequate measure of animal performance when diets with different fill characteristics are compared. With coarse diets, a relatively large proportion of LWG is rumen contents. Comparisons of animal performance and feed conversion should, instead, be done in terms of carcass gain.

Key words: roughages, carcass composition, feed conversion

\section{Introduction}

Livestock production in Finland is largely based on grass silage feeding. On controlled herds, $32 \%$ of the total feed energy for growing cattle is derived from grass silage, only $6 \%$ from hay and different types of straw, and 36\% from feed grain (LÄTTI 1991).

There are considerable differences in both the energy and protein content of grass silage, hay and straw. In general, grass silage has the highest and straw the lowest content of digestible energy and 
protein. Therefore, various levels of concentrates with a different protein content are needed to supplement these diets. The effects of different levels of concentrate supply have been studied in numerous experiments, with diets based on grass silage (e.g., SuOMI et al. 1975, 1977, VARVIKKO and LAMPILA 1984, MARTINSSON 1990, ARONEN et al. 1992), hay (e.g., LAMPILA et al. 1987) or straw (e.g., ARONEN et al. 1987, LAMPILA et al. 1987), but only a few reports are available in which different levels of concentrates with different roughages have been studied in the same experiment (e.g., LAMPILA et al. 1987).

The aim of the present experiment was to compare the feed value of grass silage, hay and oat straw as roughages for growing cattle supplemented by four different levels of concentrates. Some preliminary results have been presented earlier by LAMPILA (1988) and LAMPILA et al. (1988).

\section{Material and methods}

This study comprises three production experiments, conducted according to identical arrangements during three consecutive years.

\section{Animals and their feeding}

Each experiment included 48 Ayrshire bulls of an average initial age of 185 days and live weight of $186 \mathrm{~kg}$. Four of the bulls were lost during the experiments for reasons not related to the treatments.

The treatments were arranged according to $3 * 4$ incomplete factorial design. The roughages were fed ad libitum and different amounts of concentrates were fed as follows:

\begin{tabular}{lcccc} 
Roughage & \multicolumn{4}{c}{ Concentrate, kg/d } \\
Grass silage & 0 & 1 & 2 & 3 \\
Hay & 1 & 2 & 3 & 4 \\
Straw & 2 & 3 & 4 & 5
\end{tabular}

Direct-cut grass from a timothy-cocksfoot (Phleum pratense-Dactylis glomerata) and from a cocksfoot-timothy sward was ensiled in tower silos with a formic acid-based additive (AIV II; $80 \%$ (w/w) formic acid, $2 \%$ ortho-phosphoric acid) applied at the rate of $5 \mathrm{l} / \mathrm{t}$. The silages were of the first and second cut.

The hay used in this study was field dried and baled cocksfoot-timothy and meadow fescue-timothy (Festuca pratensis - Phleum pratense). The straw was field-dried and baled oat straw.

In grass silage-based diets, barley was fed as a concentrate, but in hay- and straw-based diets some of the barley was replaced by rapeseed meal and urea to increase and balance the nitrogen content of the diet. The animals were fed once daily and the feed intake was recorded individually. In feeding groups with a daily concentrate allowance higher than $3 \mathrm{~kg}$, the concentrates were fed in steadily growing quantities, so that the intended allowance was met during the course of the experiment. A commercial mineral mixture was fed at the rate of $150 \mathrm{~g} / \mathrm{d}$ and a vitamin mixture at the rate of 50 $\mathrm{g} /$ week. Furthermore, an injection of fat-soluble vitamins was given to the bulls on straw feeding every 10 weeks. Water was freely available. The bulls were weighed every 14 days.

\section{Analytical methods}

Feed samples were taken at every feeding and pooled for periods of two weeks for roughages and four weeks for concentrates. Proximate feed analyses were carried out conventionally. The correction for volatile losses in grass silage was made according to HUIDA et al. (1986). Fermentation quality of the grass silages was analyzed as described by VANHATALO et al. (1992). Apparent in vivo digestibility of the roughages and barley was measured in wethers, and table values (SALO et al. 1990) were applied for rapeseed meal. Metabolizable energy values of the feeds were calculated according to MAFF (1975) and values for net energy according to SALO et al. (1990).

Ruminal N degradability of the feeds was determined with three Ayrshire heifers with the feed samples originally used for proximate feed analysis. The nylon bag technique was used as described 
by ARONEN (1990). Degradability of crude protein (DEG) was calculated according to ØRSKOV and McDONALD (1979) using a rumen outflow rate (k) of $8 \% / \mathrm{h}$ as suggested by HVELPLUND and MADSEN (1990). No correction for possible small particle losses from the bags was made for concentrates. However, a correction for microbial contamination in grass silage and hay was made according to LindBERG (1988) and MichaleTDOREAU and OULD-BAH (1989), and a mean value of these two methods was adopted. DEG for straw was calculated according to LINDBERG (1988). AAT (amino acids absorbed in the small intestine) and PBV (protein balance in the rumen) were calculated according to MADSEN (1985). The digestibility of undegraded feed protein was assumed to be $82 \%$.

\section{Carcass evaluation}

Carcass weight was estimated after removal of the skin, head, feet, tail, internal organs, and kidney knob and channel fat. Fat in the abdominal cavity was calculated and carcass dissectible fat obtained as described by OLSSON and LINDBERG (1985). Carcass quality and fatness were graded visually using the carcass classification scheme employed in slaughterhouses in Finland. The gastro-intestinal tract was weighed immediately after slaughter and again after it had been emptied.

\section{Statistical analysis}

Due to the incompleteness of the factorial arrangements (the levels of concentrates used with different roughages were not equal), the effect of concentrate supplementation was analyzed separately within each roughage by an analysis of variance. In addition, the experiment year was included in the model. The effect of concentrate level was further partitioned, using orthogonal contrasts, into linear and quadratic effects. The data related to feed intake and animal performance are given as least squares means.

\section{Results and discussion}

\section{Feeds and feed intake}

Table 1 shows the average chemical composition and feed value of the experimental feeds as simple means. Both the nutritional and fermentation quality of the grass silages was good. No butyric acid was detected and the proportion of ammonia nitrogen of total nitrogen was small. The digestibility and thereby the feed value of the silages was also good. The hay had an average energy value and the energy content of the straw was relatively high.

The concentrate intake in each feeding group was as intended. Regardless of the type of roughage, increase in concentrate intake was found to decrease the roughage intake (Tables $2 \mathrm{a}-2 \mathrm{c}$ ). However, total DM intake increased linearly.

On grass silage feeding, the first $\mathrm{kg}$ of concentrates decreased grass silage intake by $0.25 \mathrm{~kg}$ $\mathrm{DM} / \mathrm{kg}$ of concentrate DM, the second by $0.70 \mathrm{~kg}$ and the third by $0.56 \mathrm{~kg}$. Intake of hay decreased by $0.84 \mathrm{~kg} \mathrm{DM} / \mathrm{kg}$ of concentrate DM, when concentrate intake was increased from $1 \mathrm{~kg}$ to $2 \mathrm{~kg}$. The third and the fourth $\mathrm{kg}$ of concentrates reduced hay intake by $0.51 \mathrm{~kg}$ and $0.73 \mathrm{~kg} \mathrm{DM} / \mathrm{kg}$ of concentrate DM, respectively. On straw feeding the depression in roughage intake was $0.34,0.67$ and 0.49 $\mathrm{kg} \mathrm{DM} / \mathrm{kg}$ of concentrate DM, respectively. On an average, the depression in roughage intake on grass silage feeding was $0.50 \mathrm{~kg} \mathrm{DM} / \mathrm{kg}$ of concentrate $\mathrm{DM}$, on hay feeding $0.69 \mathrm{~kg} \mathrm{DM}$ and on straw feeding $0.50 \mathrm{~kg} \mathrm{DM}$.

The decrease in roughage intake is usually larger with good quality roughages than with roughages of poor quality (BINES 1985). Indeed, MARTINSSON (1990) reported that per kg of concentrate DM fed, the depression in silage DM intake was greater with an early-cut $(0.76 \mathrm{~kg})$ silage than with a late-cut one $(0.64 \mathrm{~kg})$. ARONEN et al. (1992) reported a substitution rate of $0.63 \mathrm{~kg}$ silage DM per $\mathrm{kg}$ of concentrate DM. In that experiment, the digestibility of organic matter $(\mathrm{OM})$ was on average $76.3 \%$, whereas it was $73.3 \%$ in the present experiment.

Due to the varying composition of the concentrates, it is difficult to interpret the substitution rate with hay- or straw-based diets. It has been shown 
Table 1. Average chemical composition (\%), organic matter digestibility $(\%)$ and feed value of the experimental feeds and fermentation quality of grass silage.

\begin{tabular}{lrrrrr}
\hline & $\begin{array}{c}\text { Grass } \\
\text { silage }\end{array}$ & Hay & $\begin{array}{c}\text { Oat } \\
\text { straw }\end{array}$ & Barley & $\begin{array}{r}\text { Rapeseed } \\
\text { meal }\end{array}$ \\
\hline Dry matter (DM) & 23.3 & 83.8 & 82.7 & 87.8 & 89.2 \\
In DM & & & & & \\
Ash & 8.6 & 6.3 & 6.4 & 2.8 & 7.7 \\
Crude protein & 18.1 & 11.2 & 3.9 & 12.6 & 36.3 \\
Ether extract & 5.6 & 2.2 & 1.2 & 2.1 & 4.5 \\
Crude fibre & 28.8 & 33.0 & 45.5 & 4.8 & 14.6 \\
NFE & 38.8 & 47.3 & 43.0 & 77.7 & 36.9 \\
OM digestibility & 73.3 & 65.8 & 52.8 & 83.1 & 75.0 \\
Feed value & & & & & \\
FU/kg DM & 0.74 & 0.57 & 0.34 & 1.12 & 0.96 \\
ME, MJ/kg DM & 10.60 & 9.32 & 7.15 & 13.08 & 11.42 \\
DCP, g/kg DM & 138 & 67 & 14 & 91 & 303 \\
AAT, g/kg DM & 66 & 72 & 58 & 87 & 110 \\
PBV, g/kg DM & 67 & -13 & -60 & -17 & 71 \\
DEG, \%1 & 84 & 74 & 67 & 87 & \\
pH & 3.97 & & & & \\
In fresh feed & & & & & \\
Sugars & 0.98 & & & & \\
Lactic acid & 1.16 & & & & \\
Acetic acid & 0.32 & & & & \\
Ethanol & 0.16 & & & & \\
In total N (g/kg) & 511 & & & & \\
Soluble N & 40 & & & & \\
Ammonium N & & & & & \\
\hline
\end{tabular}

DEG without correction for microbial contamination in grass silage and hay was 72 and 56, respectively. NFE, nitrogen free extracts; FU, feed unit; ME, metabolizable energy; MJ, megajoule; DCP, digestible crude protein; AAT, amino acids absorbed in the small intestine; PBV, protein balance in the rumen; DEG, degradability of feed protein; $\mathrm{N}$, nitrogen.

that protein feeds with differing degradability may have a different effect on roughage intake (e.g., ARONEN 1990).

The increase in concentrate feeding level resulted in an increase both in energy and protein intake (Tables 2a-2c). The increase in protein intake with animals fed grass silage was relatively larger when the protein intake was calculated as AAT than when calculated as crude protein or digestible crude protein. The calculated PBV was clearly higher for grass silage diets than for hay or straw diets. In other words, there was a large excess of rumen degradable protein in grass silage diets. However, increasing the level of concentrates reduced this excess. At the same time, LWG in- creased (Table 3a), thereby increasing the protein deposition in the tissues. Thus, raising the concentrate level improved the nitrogen utilization on grass silage feeding.

\section{Animal performance}

Regardless of the roughage, the increase in concentrate intake resulted in a faster rate of daily live weight gain (LWG) (Figure 1). This effect was linear. Raising the amount of concentrates had a similar effect on carcass gain (Tables 3a-3c). These findings are in accordance with results reported by SuOMI et al. (1975) and ARONEN et al. (1987), who, 
Table 2a. Effect of concentrate supplementation on feed intake and estimated nutrient consumption in growing cattle on grass silage feeding.

\begin{tabular}{|c|c|c|c|c|c|c|c|}
\hline \multirow{2}{*}{$\begin{array}{l}\text { Concentrates } \\
\mathrm{n}\end{array}$} & \multirow{2}{*}{$\begin{array}{c}0 \mathrm{~kg} \\
11\end{array}$} & \multirow{2}{*}{$\begin{array}{c}1 \mathrm{~kg} \\
11\end{array}$} & \multirow{2}{*}{$\begin{array}{c}2 \mathrm{~kg} \\
12\end{array}$} & \multirow{2}{*}{$\begin{array}{c}3 \mathrm{~kg} \\
12\end{array}$} & \multirow[t]{2}{*}{ SEM } & \multicolumn{2}{|c|}{$\begin{array}{l}\text { Effect of } \\
\text { concentrate }\end{array}$} \\
\hline & & & & & & L & Q \\
\hline \multicolumn{8}{|l|}{$\begin{array}{l}\text { Feed intake, } \\
\mathrm{kg} \mathrm{DM} / \mathrm{d}\end{array}$} \\
\hline Grass silage & 5.66 & 5.45 & 4.86 & 4.36 & 0.159 & $* * *$ & NS \\
\hline Barley & - & 0.85 & 1.69 & 2.59 & & & \\
\hline Minerals & 0.15 & 0.15 & 0.15 & 0.15 & & & \\
\hline Total & 5.81 & 6.45 & 6.69 & 7.10 & 0.159 & $* * *$ & NS \\
\hline \multicolumn{8}{|l|}{ Energy intake } \\
\hline $\mathrm{FU} / \mathrm{d}$ & 4.17 & 4.96 & 5.46 & 6.11 & 0.115 & $* * *$ & NS \\
\hline \multicolumn{8}{|l|}{ Protein intake } \\
\hline $\mathrm{CP}, \mathrm{g} / \mathrm{d}$ & 1021 & 1089 & 1090 & 1113 & 28.0 & $*$ & NS \\
\hline DCP, g/d & 763 & 808 & 808 & 821 & 20.9 & o & NS \\
\hline AAT, g/d & 369 & 429 & 463 & 508 & 10.3 & $* * *$ & NS \\
\hline PBV & 390 & 360 & 306 & 256 & 11.0 & $* * *$ & NS \\
\hline
\end{tabular}

Table 2b. Effect of concentrate supplementation on feed intake and estimated nutrient consumption in growing cattle on hay feeding.

\begin{tabular}{|c|c|c|c|c|c|c|c|}
\hline \multirow{2}{*}{$\begin{array}{l}\text { Concentrates } \\
\mathrm{n}\end{array}$} & \multirow{2}{*}{$\begin{array}{c}1 \mathrm{~kg} \\
12\end{array}$} & \multirow{2}{*}{$\begin{array}{c}2 \mathrm{~kg} \\
12\end{array}$} & \multirow{2}{*}{$\begin{array}{c}3 \mathrm{~kg} \\
11\end{array}$} & \multirow{2}{*}{$\begin{array}{c}4 \mathrm{~kg} \\
12\end{array}$} & \multirow[t]{2}{*}{ SEM } & \multicolumn{2}{|c|}{$\begin{array}{c}\text { Effect of } \\
\text { concentrates }\end{array}$} \\
\hline & & & & & & $\mathrm{L}$ & Q \\
\hline \multicolumn{8}{|l|}{$\begin{array}{l}\text { Feed intake, } \\
\mathrm{kg} \mathrm{DM} / \mathrm{d}\end{array}$} \\
\hline Hay & 5.14 & 4.42 & 3.96 & 3.35 & 0.141 & $* * *$ & NS \\
\hline Barley & 0.40 & 1.65 & 2.56 & 3.39 & & & \\
\hline Rapeseed meal & 0.43 & - & - & - & & & \\
\hline Urea & 0.03 & 0.07 & 0.06 & 0.05 & & & \\
\hline Minerals & 0.15 & 0.15 & 0.15 & 0.15 & & & \\
\hline Total & 6.15 & 6.30 & 6.74 & 6.95 & 0.141 & $* * *$ & NS \\
\hline \multicolumn{8}{|l|}{ Energy intake } \\
\hline $\mathrm{FU} / \mathrm{d}$ & 3.88 & 4.45 & 5.20 & 5.77 & 0.085 & $* * *$ & NS \\
\hline \multicolumn{8}{|l|}{ Protein intake } \\
\hline $\mathrm{CP}, \mathrm{g} / \mathrm{d}$ & 859 & 897 & 935 & 948 & 16.5 & $* * *$ & NS \\
\hline DCP, g/d & 587 & 627 & 656 & 667 & 10.6 & $* * *$ & NS \\
\hline AAT, g/d & 453 & 462 & 507 & 536 & 10.1 & $* * *$ & NS \\
\hline PBV & 98 & 119 & 84 & 49 & 4.2 & $* * *$ & $* * *$ \\
\hline
\end{tabular}

in their studies, included increasing amounts of barley in grass silage-based diets or in diets based on oat straw, respectively.

A rather good LWG was obtained with grass silage alone. However, the results clearly show that the total growth potential of the Ayrshire bulls could not be utilized by feeding the bulls with grass silage alone or grass silage with small ( 1 to $2 \mathrm{~kg} / \mathrm{d}$ ) amounts of concentrates.

The differences in carcass gain between the different roughages were clear. To obtain an equal carcass gain, $2 \mathrm{~kg}$ more of concentrates was needed on hay feeding than on grass silage feeding. Furthermore, on straw feeding, $4 \mathrm{~kg}$ of concentrates 
Table 2c. Effect of concentrate supplementation on feed intake and estimated nutrient consumption in growing cattle on straw feeding.

\begin{tabular}{|c|c|c|c|c|c|c|c|}
\hline \multirow{2}{*}{$\begin{array}{l}\text { Concentrates } \\
\mathrm{n}\end{array}$} & \multirow{2}{*}{$\begin{array}{c}2 \mathrm{~kg} \\
12\end{array}$} & \multirow{2}{*}{$\begin{array}{c}3 \mathrm{~kg} \\
11\end{array}$} & \multirow{2}{*}{$\begin{array}{c}4 \mathrm{~kg} \\
12\end{array}$} & \multirow{2}{*}{$\begin{array}{c}5 \mathrm{~kg} \\
12\end{array}$} & \multirow[t]{2}{*}{ SEM } & \multicolumn{2}{|c|}{$\begin{array}{c}\text { Effect of } \\
\text { concentrates }\end{array}$} \\
\hline & & & & & & $\mathrm{L}$ & Q \\
\hline \multicolumn{8}{|l|}{$\begin{array}{l}\text { Feed intake, } \\
\mathrm{kg} \mathrm{DM} / \mathrm{d}\end{array}$} \\
\hline Straw & 3.25 & 2.95 & 2.38 & 1.96 & 0.121 & $* * *$ & NS \\
\hline Barley & 1.04 & 2.28 & 3.41 & 4.28 & & & \\
\hline Rapeseed meal & 0.66 & 0.27 & - & - & & & \\
\hline Urea & 0.08 & 0.10 & 0.11 & 0.10 & & & \\
\hline Minerals & 0.15 & 0.15 & 0.15 & 0.15 & & & \\
\hline Total & 5.19 & 5.76 & 6.06 & 6.50 & 0.120 & $* * *$ & NS \\
\hline \multicolumn{8}{|l|}{ Energy intake } \\
\hline $\mathrm{FU} / \mathrm{d}$ & 2.92 & 3.84 & 4.64 & 5.47 & 0.043 & $* * *$ & NS \\
\hline \multicolumn{8}{|l|}{ Protein intake } \\
\hline $\mathrm{CP}, \mathrm{g} / \mathrm{d}$ & 712 & 782 & 832 & 898 & 5.8 & $* * *$ & NS \\
\hline DCP, g/d & 527 & 578 & 617 & 666 & 3.1 & $* * *$ & NS \\
\hline AAT, g/d & 351 & 399 & 435 & 486 & 6.9 & $* * *$ & NS \\
\hline PBV & 138 & 124 & 111 & 92 & 7.4 & $* * *$ & $* * *$ \\
\hline
\end{tabular}

SEM, standard error of mean; NS, statistically non-significant; ${ }^{*}, \mathrm{p}<0.05$; $^{* *}, \mathrm{p}<0.01{ }^{* * *}, \mathrm{p}<0.001$; L, linear effect; Q, cubic effect; DM, dry matter; FU, feed unit; CP, crude protein; DCP, digestible crude protein; AAT, amino acids absorbed in the small intestine; PBV, protein balance in the rumen.

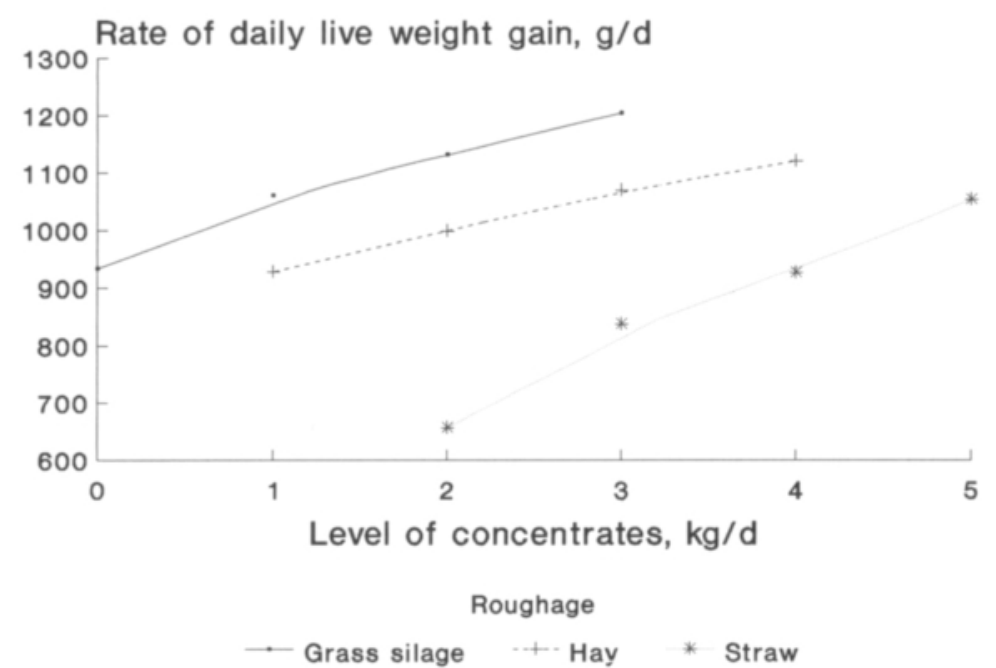

Fig. 1. Average daily live weight gain of the bulls. was not enough to obtain comparable carcass gain as with grass silage alone.

When the calculated energy intake in fattening feed units was plotted against daily carcass gain (Figure 2), the relative value of the different rough- ages could be compared. It was shown that, in order to obtain a similar carcass gain, more energy was needed on straw than on hay feeding and that more energy was needed on hay than on grass silage feeding. This observation may imply two things 
Table 3a. Effect of concentrate supplementation on the rate of live weight gain (LWG), carcass gain (CG) and feed conversion on grass silage feeding.

\begin{tabular}{lcrrrrrr}
\hline & & & & & & \multicolumn{2}{c}{ Effect of } \\
Concentrates & $0 \mathrm{~kg}$ & $1 \mathrm{~kg}$ & $2 \mathrm{~kg}$ & $3 \mathrm{~kg}$ & $\mathrm{SEM}$ & \multicolumn{2}{c}{ concentrates } \\
$\mathrm{n}$ & 11 & 11 & 12 & 12 & & & $\mathrm{~L}$ \\
\hline $\begin{array}{l}\text { Live weight, kg } \\
\quad \text { Initial }\end{array}$ & 189 & 185 & 186 & 184 & 7.3 & $\mathrm{NS}$ & $\mathrm{NS}$ \\
$\quad$ Final & 398 & 422 & 439 & 454 & 11.4 & $* * *$ & $\mathrm{NS}$ \\
LWG, g/d & 933 & 1061 & 1132 & 1205 & 29.7 & $* * *$ & $\mathrm{NS}$ \\
CG, g/pv & 454 & 545 & 603 & 640 & 17.4 & $* * *$ & $\mathrm{NS}$ \\
Feed conversion, & & & & & & & \\
$\quad$ FU/kg LWG & 4.5 & 4.7 & 4.8 & 5.1 & 0.11 & $* * *$ & $\mathrm{NS}$ \\
$\quad$ FU/kg CG & 9.2 & 9.1 & 9.1 & 9.6 & 0.23 & NS & NS \\
\hline
\end{tabular}

Table 3b. Effect of concentrate supplementation on the rate of live weight gain (LWG), carcass gain (CG) and feed conversion on hay feeding.

\begin{tabular}{|c|c|c|c|c|c|c|c|}
\hline \multirow{2}{*}{$\begin{array}{l}\text { Concentrates } \\
\mathrm{n}\end{array}$} & \multirow{2}{*}{$\begin{array}{c}1 \mathrm{~kg} \\
12\end{array}$} & \multirow{2}{*}{$\begin{array}{c}2 \mathrm{~kg} \\
12\end{array}$} & \multirow{2}{*}{$\begin{array}{c}3 \mathrm{~kg} \\
11\end{array}$} & \multirow{2}{*}{$\begin{array}{c}4 \mathrm{~kg} \\
12\end{array}$} & \multirow[t]{2}{*}{ SEM } & \multicolumn{2}{|c|}{$\begin{array}{l}\text { Effect of } \\
\text { concentrates }\end{array}$} \\
\hline & & & & & & $\mathrm{L}$ & Q \\
\hline \multicolumn{8}{|l|}{ Live weight, $\mathrm{kg}$} \\
\hline Initial & 183 & 183 & 190 & 183 & 7.5 & NS & NS \\
\hline Final & 391 & 406 & 430 & 434 & 11.2 & ** & NS \\
\hline LWG, g/d & 928 & 999 & 1070 & 1121 & 27.8 & $* * *$ & NS \\
\hline $\mathrm{CG}, \mathrm{g} / \mathrm{d}$ & 413 & 464 & 532 & 573 & 14.2 & $* * *$ & NS \\
\hline \multicolumn{8}{|l|}{ Feed conversion } \\
\hline FU/kg LWG & 4.2 & 4.5 & 4.9 & 5.2 & 0.11 & $* * *$ & NS \\
\hline $\mathrm{FU} / \mathrm{kg} \mathrm{CG}$ & 9.4 & 9.7 & 9.8 & 10.2 & 0.26 & $*$ & NS \\
\hline
\end{tabular}

Table 3c. Effect of concentrate supplementation on the rate of live weight gain (LWG), carcass gain (CG) and feed conversion on straw feeding.

\begin{tabular}{|c|c|c|c|c|c|c|c|}
\hline \multirow{2}{*}{$\begin{array}{l}\text { Concentrates } \\
\mathrm{n}\end{array}$} & \multirow{2}{*}{$\begin{array}{c}2 \mathrm{~kg} \\
12\end{array}$} & \multirow{2}{*}{$\begin{array}{c}3 \mathrm{~kg} \\
11\end{array}$} & \multirow{2}{*}{$\begin{array}{c}4 \mathrm{~kg} \\
12\end{array}$} & \multirow{2}{*}{$\begin{array}{c}5 \mathrm{~kg} \\
12\end{array}$} & \multirow[t]{2}{*}{ SEM } & \multicolumn{2}{|c|}{$\begin{array}{c}\text { Effect of } \\
\text { concentrates }\end{array}$} \\
\hline & & & & & & $\mathrm{L}$ & Q \\
\hline \multicolumn{8}{|l|}{ Live weight, $\mathrm{kg}$} \\
\hline Initial & 186 & 182 & 187 & 185 & 6.0 & NS & NS \\
\hline Final & 333 & 369 & 395 & 421 & 7.8 & $* * *$ & NS \\
\hline LWG, g/d & 657 & 838 & 927 & 1054 & 22.4 & $* * *$ & NS \\
\hline $\mathrm{CG}, \mathrm{g} / \mathrm{d}$ & 223 & 351 & 433 & 534 & 13.1 & $* * *$ & NS \\
\hline \multicolumn{8}{|l|}{ Feed conversion } \\
\hline FU/kg LWG & 4.5 & 4.6 & 5.0 & 5.2 & 0.11 & $* * *$ & NS \\
\hline $\mathrm{FU} / \mathrm{kg} \mathrm{CG}$ & 13.4 & 11.0 & 10.9 & 10.4 & 0.43 & $* * *$ & $*$ \\
\hline
\end{tabular}

SEM, standard error of mean; NS, statistically non-significant; ${ }^{*}, \mathrm{p}<0.05 ;{ }^{* *}, \mathrm{p}<0.01 ;{ }^{* * *}, \mathrm{p}<0.001$; L, linear effect; Q, cubic effect; FU, feed unit. 


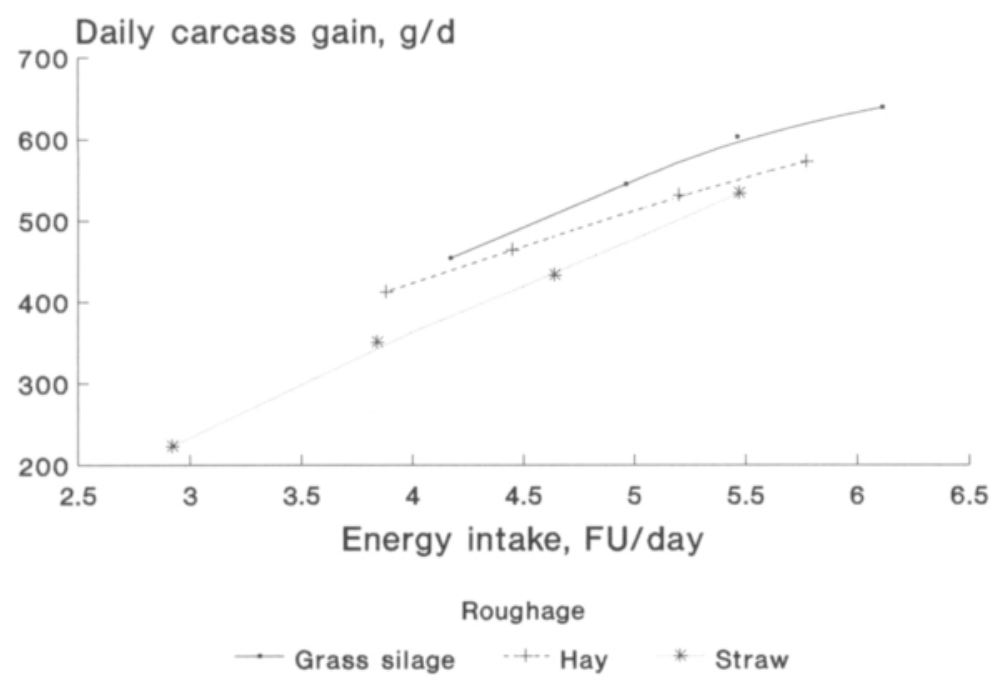

Fig. 2. Average daily carcass gain and energy intake of the bulls. about the finnish energy system. Firstly, it is possible that the system overestimates the feed value of hay and straw compared to grass silage and that the feed value of straw is overestimated compared to hay. Secondly, it is possible that, compared to barley, the feed value of roughages may be underestimated. These findings were already reported by LAMPILA and MiCORDIA (1990), and a working group has been established to re-evaluate the present energy system used in Finland.

Due to experimental arrangements, the concentrate level and weight at slaughter are confounding. Therefore, the results related to feed conversion and carcass composition should be interpreted with caution.

Regardless of the type of roughage, increasing the intake of concentrate was found to impair feed conversion in feed units per $\mathrm{kg}$ of daily live weight gain (Tables 3a-3c). This observation is in line with the results reported by SuOMI et al. (1975) and ARONEN et al. (1992). However, it has to be pointed out that because the duration of the feeding experiment was the same for each feeding group, the animals receiving more concentrates were relatively more matured due to a higher live weight and faster LWG, and they inevitably contained more fat. According to GEAY and MiCOL (1989), the higher the LWG and energy intake, the more rapidly fat is deposited in the carcass. Results reported by ANDERSEN et al. (1984) and BAILEY (1989) support this concept. This, together with the higher live weight at slaughter and concomitant higher maintenance requirement, could explain the impaired feed conversion with high concentrate diets.

When feed conversion was calculated in feed units per $\mathrm{kg}$ of carcass gain, the results were less consistent. On grass silage feeding, the increase in concentrate intake at lower levels of concentrate supply had a positive effect on feed conversion, but the poorest feed conversion was measured at the highest concentrate level. On hay feeding, increasing the level of concentrates impaired feed conversion, whereas the opposite was true on straw feeding.

An increase in concentrate feeding level had a positive effect on dressing percentage within each roughage (Tables $4 \mathrm{a}-4 \mathrm{c}$ ). The improvement in dressing percentage seemed to be curvilinear, at least in grass silage diets. SUOMI et al. (1975), VARVIKKO and LAMPILA (1984) and MARTINSSON (1990) also reported an improved dressing percentage with an increased concentrate feeding level.

Increasing the level of concentrates in the diet improved the carcass quality grade. However, on grass silage feeding the best score was recorded when the second highest level of concentrates was applied. More subcutaneous fat was deposited when the level of concentrates was raised, as indi- 
Table 4a. Effect of concentrate supplementation on slaughter data on grass silage feeding.

\begin{tabular}{|c|c|c|c|c|c|c|c|}
\hline \multirow{2}{*}{$\begin{array}{l}\text { Concentrates } \\
\mathrm{n}\end{array}$} & \multirow{2}{*}{$\begin{array}{c}0 \mathrm{~kg} \\
11\end{array}$} & \multirow{2}{*}{$\begin{array}{c}1 \mathrm{~kg} \\
11\end{array}$} & \multirow{2}{*}{$\begin{array}{c}2 \mathrm{~kg} \\
12\end{array}$} & \multirow{2}{*}{$\begin{array}{c}3 \mathrm{~kg} \\
12\end{array}$} & \multirow[t]{2}{*}{ SEM } & \multicolumn{2}{|c|}{$\begin{array}{l}\text { Effect of } \\
\text { concentrates }\end{array}$} \\
\hline & & & & & & $\mathrm{L}$ & $\mathrm{Q}$ \\
\hline Carcass weight, kg & 191 & 208 & 222 & 229 & 6.1 & $* * *$ & NS \\
\hline Dressing $\%$ & 47.8 & 49.3 & 50.4 & 50.4 & 0.41 & $* * *$ & o \\
\hline Quality grade & 7.6 & 8.1 & 8.4 & 8.2 & 0.15 & $* *$ & $*$ \\
\hline Fatness grade & 0.6 & 1.0 & 1.0 & 1.2 & 0.08 & $* * *$ & NS \\
\hline $\begin{array}{l}\text { Fat in abdominal } \\
\text { cavity, kg }\end{array}$ & 11.8 & 15.2 & 17.5 & 20.3 & 1.04 & $* * *$ & NS \\
\hline $\begin{array}{l}\text { Carcass dissectible } \\
\text { fat, } \mathrm{kg}\end{array}$ & 9.3 & 12.0 & 13.3 & 15.3 & 1.16 & $* * *$ & NS \\
\hline $\begin{array}{l}\text { Gastrointestinal tract } \\
\text { full, kg }\end{array}$ & 95.5 & 91.7 & 82.6 & 76.3 & 2.82 & * & NS \\
\hline empty, kg & 24.7 & 25.8 & 26.2 & 26.6 & 0.91 & NS & NS \\
\hline difference, $\mathrm{kg}$ & 70.8 & 65.9 & 56.3 & 49.7 & 2.21 & $* *$ & NS \\
\hline
\end{tabular}

Table $4 \mathrm{~b}$. Effect of concentrate supplementation on slaughter data on hay feeding.

\begin{tabular}{|c|c|c|c|c|c|c|c|}
\hline \multirow{2}{*}{$\begin{array}{l}\text { Concentrates } \\
\mathrm{n}\end{array}$} & \multirow{2}{*}{$\begin{array}{c}1 \mathrm{~kg} \\
12\end{array}$} & \multirow{2}{*}{$\begin{array}{c}2 \mathrm{~kg} \\
12\end{array}$} & \multirow{2}{*}{$\begin{array}{c}3 \mathrm{~kg} \\
11\end{array}$} & \multirow{2}{*}{$\begin{array}{c}4 \mathrm{~kg} \\
12\end{array}$} & \multirow[t]{2}{*}{ SEM } & \multicolumn{2}{|c|}{$\begin{array}{c}\text { Effect of } \\
\text { concentrates }\end{array}$} \\
\hline & & & & & & $\mathrm{L}$ & $\mathrm{Q}$ \\
\hline Carcass weight, $\mathrm{kg}$ & 179 & 190 & 208 & 213 & 5.5 & $* * *$ & NS \\
\hline Dressing $\%$ & 45.7 & 46.7 & 48.5 & 49.1 & 0.39 & $* * *$ & NS \\
\hline Quality grade & 7.6 & 7.8 & 8.0 & 8.1 & 0.17 & * & NS \\
\hline Fatness grade & 0.4 & 0.8 & 0.9 & 0.9 & 0.12 & $* *$ & NS \\
\hline $\begin{array}{l}\text { Fat in abdominal } \\
\text { cavity, kg }\end{array}$ & 9.1 & 11.3 & 13.4 & 15.8 & 0.70 & $* * *$ & NS \\
\hline $\begin{array}{l}\text { Carcass dissectible } \\
\text { fat, } \mathrm{kg}\end{array}$ & 6.6 & 7.9 & 10.1 & 13.0 & 0.78 & *** & NS \\
\hline Gastrointestinal tra & & & & & & & \\
\hline $\begin{array}{l}\text { full, kg } \\
\text { empty, kg }\end{array}$ & $\begin{array}{l}95.2 \\
23.7\end{array}$ & $\begin{array}{r}101.5 \\
25.5\end{array}$ & $\begin{array}{l}89.9 \\
24.6\end{array}$ & $\begin{array}{l}97.4 \\
27.9\end{array}$ & $\begin{array}{l}5.32 \\
1.69\end{array}$ & $\begin{array}{c}\mathrm{o} \\
\mathrm{NS}\end{array}$ & $\begin{array}{l}\text { NS } \\
\text { NS }\end{array}$ \\
\hline difference, $\mathrm{kg}$ & 71.5 & 76.0 & 65.3 & 69.5 & 4.17 & NS & NS \\
\hline
\end{tabular}

cated by the higher carcass fat grade and the increased amount of carcass dissectible fat (Tables $4 a-4 c)$. This result is in agreement with the findings reported by LAMPILA et al. (1987) with various roughages, MARTINSSON (1990) and ARONEN et al. (1992) with grass silage-based diets, and ARONEN et al. (1987) with straw-based diets.

The amount of fat in the abdominal cavity in- creased when the level of concentrates was increased (Tables $4 a-4 c)$. There was a close relation between this fat and carcass weight. This finding is in accordance with the observation that growing cattle with a high live weight deposit more fat than protein (GEAY and MiCOL 1989). On the other hand, it must be pointed out that in the present experiment, the animals having a higher carcass 
Table 4c. Effect of concentrate supplementation on slaughter data on straw feeding.

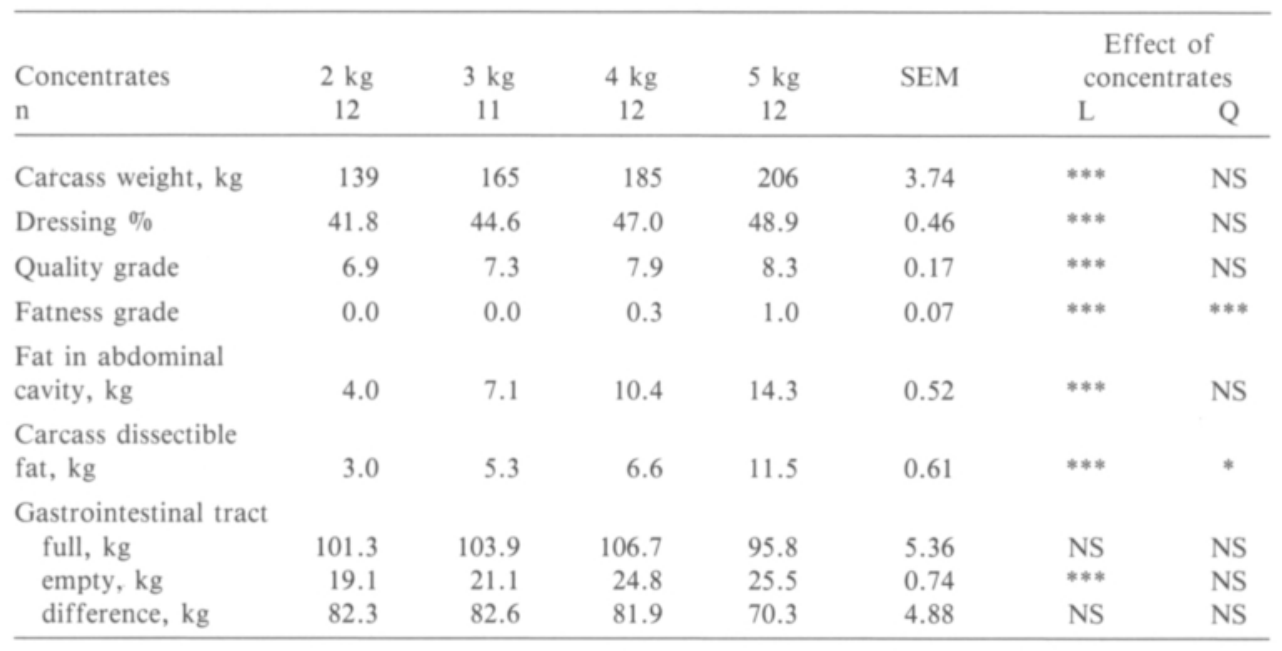

SEM, standard error of mean; NS, statistically non-significant; ${ }^{*}, \mathrm{p}<0.05 ;^{* *}, \mathrm{p}<0.01 ;{ }^{* * *}, \mathrm{p}<0.001$; $\mathrm{L}$, linear effect; $\mathrm{Q}$, cubic effect;

Quality grade: $5=$ skinny $-10=$ very muscular.

Fatness grade: $0=$ leanest $(\mathrm{T})-4=$ fatty carcass $(\mathrm{R})$.

Fat in abdominal cavity: The sum of kidney knob and channel fat, omentum and mesentric fat.

weight at slaughter also had a higher LWG. Indeed, ANDERSEN et al. (1984) observed that to obtain a given carcass weight, a higher level of feeding (and a concomitant increase in LWG) increased the relative amount of fat.

The changes in the amount of fat in the abdominal cavity and of carcass dissectible fat within each roughage were linear. However, when the data are studied as a whole, it can be seen that the changes were curvilinear and that the relatively highest fat accretion was recorded with the highest carcass weights (Figure 3). However, as stated earlier, it is not possible to distinguish whether the above differences in carcass composition were caused by different carcass weights at slaughter or by differences in LWG or, more likely, by both.

In all diets, the increase in concentrate feeding level was found to reduce the contents of the gastrointestinal tract (Tables 4a-4c). Similarly, there were large differences in the contents of the gastro-intestinal tract between the different types of roughages. Analogously, Отто et al. (1980) found straw feed- ing to increase the contents of the gastro-intestinal tract when compared to grass silage feeding. This suggests that live weight and LWG are not proper measures to use when diets with different fill characteristics are compared.

\section{Conclusions}

The results of the present experiment show that grass silage is of superior nutritional value compared to hay or straw. To obtain an equal carcass gain, $2 \mathrm{~kg}$ more of concentrates was needed on hay feeding than on grass silage feeding. On straw feeding, $4 \mathrm{~kg}$ of concentrates was not enough to obtain a comparable carcass gain as with grass silage alone. However, the response in carcass gain to concentrate supplementation on grass silage feeding indicated that the growth potential of the bulls receiving silage alone or silage with small amounts ( 1 or $2 \mathrm{~kg} /$ day) of concentrates was not completely utilized. 

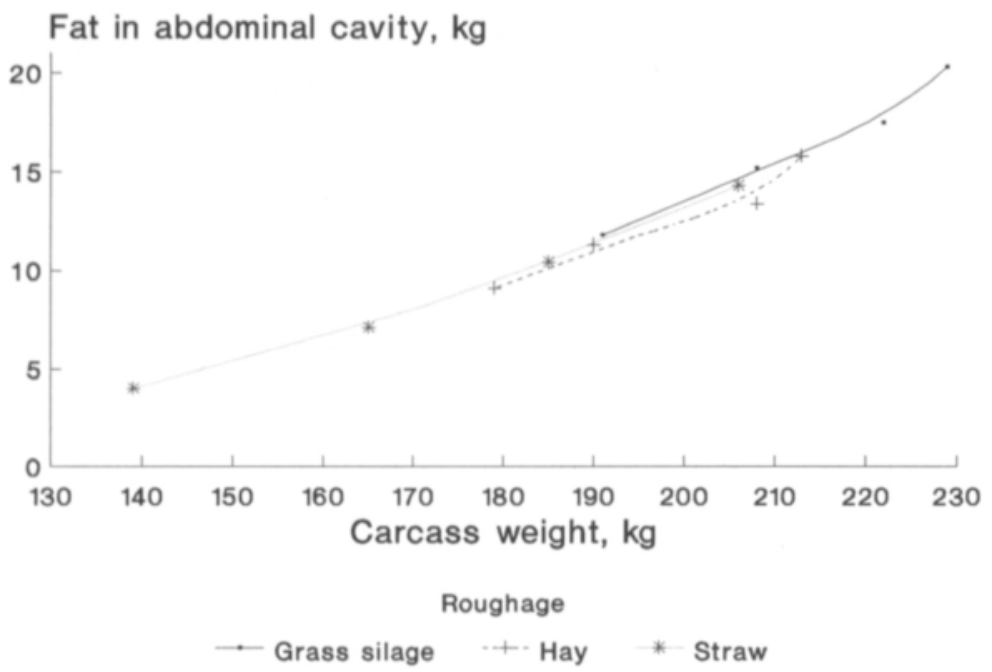

Fig. 3. Relationship between carcass weight and amount of fat in the abdominal cacity.
The results show that live weight and rate of live weight gain are inadequate measures of animal performance when diets with different fill characteristics are compared. With coarse diets, a relatively large proportion of the gain is rumen contents. Comparisons of animal performance and feed conversion between different diets should, instead, be done in terms of carcass gain. Furthermore, the results clearly indicate that the present energy evaluation system employed in Finland needs to be re-evaluated.

\section{References}

Aronen, I. 1990. Barley protein and rapeseed meal as protein supplements for growing cattle. Acta Agriculturae Scandinavica 40: 297-307.

-, Hepola, H., Alaspäă, M. \& Lampila, M. 1987. Erisuuruiset väkirehuannokset kasvavien ayrshire-sonnien olkiruokinnassa. Maatalouden tutkimuskeskus, Tiedote 21/87. p. 41-66.

—, Tolvonen, V., Ketoja, E. \& Öfversten, J. 1992. Beef production as influenced by stage of maturity of grass for silage and level and type of supplementary concentrates. Agricultural Science in Finland 1: 441-460.

BAILEY, C.B. 1989. Carcass composition of steers given hay, hay supplemented with ruminal undegraded protein, or concentrate. Canadian Journal of Animal Science 69: 905-909.

BinEs, J.A. 1985. Feeding systems and food intake by housed dairy cows. Proceedings of the Nutrition Society 44: 355-362.

GeAY, Y. \& Micol, D. 1989. Growing and finishing cattle. In: Jarrige, R. (ed.). Ruminant nutrition. Recommended allowances \& feed tables. John Libbey and Co Ltd, England. p. 121-151.

HuIdA, L., VĂÄTÄInen, H. \& LAMPILA, M. 1986. Comparison of dry matter contents in grass silages as determined by oven drying and gas chromatographic water analysis. Annales Agriculturae Fenniae 25: 215-230.

Hvelplund, T. \& Madsen, J. 1990. A study of the quantitative nitrogen metabolism in the gastro-intestinal tract and the resultant new protein evaluation system for ruminants. The AAT-PBV system. Institute of Animal Science. The Royal Vet. and Agric. Univ., Copenhagen. Diss. 215 p.

LAMPILA, M. 1988. Säilörehuruokinta edullisinta. Karjatalous 5: 28-29.

—, JaAkKola, S., Toivonen, V. \& Setälä, J. 1988. Forage conservation and supplementation in cattle rations. Proceedings of the VI World Conference on Animal Production, Helsinki. p. 51-71.

— \& MiCORDIA, A. 1990. Lihanautojen tarvenormien vertailu eläinkokeiden perusteella. Suomen Maataloustieteellisen Seuran Tiedote No. 13. p. 15-29.

—, VĂÄTÄInen, H. \& Al_AspäĀ, M. 1987. Korsirehujen vertailu kasvavien ayrshire-sonnien ruokinnassa. Maatalouden tutkimuskeskus, Tiedote 21/87. p. 1-40.

LÄTTI, M. 1991. Naudanlihantuotannon T-tarkkailu 1991. Maaseutukeskusten Liitto. 
LINDBERG, J.E. 1988. Influence of cutting time and $\mathrm{N}$ fertilization on the nutritive value of timothy. 2 . Estimation of rumen degradability of nitrogenous compounds. Swedish Journal of agricultural Research 18: 85-89.

MADSEN, J. 1985. The basis for the proposed Nordic protein evaluation system for rumninants. The AAT-PBV-system. Acta Agriculturae Scandinavica, Suppl. 25: 9-20.

MAFF 1975. Energy allowances and feeding systems for ruminants. Ministry of Agriculture, Fisheries and Food, Tech. Bull. 33, HMSO, London. 79 p.

Martinsson, K. 1990. The effect of forage digestibility and concentrate supplementation on performance of finishing bulls. Swedish Journal of agricultural Research 20: 161167.

Michalet-Doreau, B. \& Ould-Bah, M.Y. 1989. Estimation of the extent of bacterial contamination in bag residues and its influence on in sacco measurements of forage nitrogen degradation in the rumen. XVI International Grassland Congress, Nice, France. p. 909-910.

OLsSON, I. \& LindBERG, J.E. 1985. Performance of bull calves fed rations with different calculated amino acid flow to the duodenum. Acta Agriculturae Scandinavica, Suppl. 25: 184-193.

Ørskov, E.R. \& McDonald, I. 1979. The estimation of protein degradability in the rumen from incubation measurements weighted according to rate of passage. Journal of Agricultural Science, Cambridge 92: 499-503.

Otto, E., Papstein, H.J. \& Bergner, E. 1980. Effect of pelleted cereal straw in the ration on performance of young bulls (beef crosses). 2. Carcass yield and nutritive value of the carcasses. Archiv für Tierernährung 30 : 853-858.

SAlo, M.-L., TuORI, M. \& KIISKInEN, T. 1990. Rehutaulukot ja ruokintanormit, 70 p. Helsinki.

Suomi, K., Hakкol.a, H. \& Kossil.a, V. 1977. Säilörehun korjuuasteen vaikutus naudanlihantuotannossa. Maatalouden tutkimuskeskus, Pohjois-Pohjanmaan koeaseman tiedote N:o 1. 15 p.

—, Kossila, V., Hakkola, H. \& LampIla, M. 1975. Eri väkirehumäärien vaikutus lihanautojen kasvuun. Maatalouden tutkimuskeskus, Pohjois-Pohjanmaan koeaseman tiedote N:o 2. p. 1-6.

Vanhatalo, A., Varvikko, T. \& Aronen, I. 1992. The effect of type of additive on rumen fermentation and digestion of grass silage in cattle. Agricultural Science in Finland 1: 163-175.

VARVIKKO, T. \& LAMPILA, M. 1984. Väkirehutason vaikutus lihamullin kasvu- ja teurastulokseen säilörehuruokinnalla. Koetoiminta ja Käytäntö 41: 38.

Manuscript received June 1993

\title{
SELOSTUS
}

\section{Säilörehu, heinä ja olki kasvavien ayrshire-sonnien ruokinnassa}

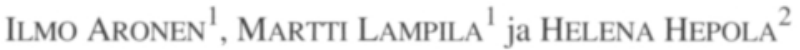 \\ ${ }^{1}$ Maatalouden tutkimuskeskus ja ${ }^{2}$ Helsingin yliopisto
}

Tämä tutkimus koostuu kolmesta, peräkkäisinä vuosina saman koekaavion mukaan tehdystä lihantuotantokokeesta. Tutkimuksessa oli yhteensä 144 ayrshire-sonnia. Kokeiden alkaessa eläimet olivat keskimäärin 185 päivän ikäisiä ja 186 kilon painoisia. Koe kesti kaikilla eläimillä 224 pv. Vertailtavat, vapaasti tarjolla olleet korsirehut olivat nurmisäilörehu, heină ja kauranolki täydennettynä neljällä erisuurella väkirehuannoksella. Väkirehun päiväannokset olivat säilörehuruokinnalla $0,1,2$ ja 3 kg, heinäruokinnalla 1,2, 3 ja 4 kg sekä olkiruokinnalla 2, 3, 4 ja 5 kg. Väkirehuna oli pääasiassa ohra. Heinä- ja olkiryhmien eläimet saivat lisäksi valkuaistäydennyksenä rypsiä ja ureaa typen saannin tasoittamiseksi.

Karkearehusta riippumatta väkirehuannoksen suurentaminen vähensi karkearehun syöntiä. Rehujen kuiva-aineen syönti yhteensä kuitenkin lisääntyi. Jokainen văkirehutaso lisäsi päiväkasvua ja ruhotuotosta edelliseen tasoon verrattuna.

Saman ruhotuotoksen saavuttamiseksi heinäruokinnalla tarvittiin keskimäärin kaksi kiloa enemmän väkirehua kuin säilörehuruokinnalla. Olkiruokinnalla ei edes 4 kilon väkire- hutäydennys riittänyt samaan ruhotuotokseen kuin säilörehu ilman täydennystä. Kuitenkin väkirehulla saatu tuotantovaikutus osoitti, että pelkällä säilörehulla tai säilörehulla ja pienellä (1-2 kg/pv) väkirehumäärällä ruokittaessa eläimen kasvupotentiaalista osa jää käyttämättä. Säilörehuruokinnalla väkirehun sisällyttäminen rehuannokseen paransi myös säilörehun typen hyväksikäyttöä. Väkirehuannoksen suurentaminen lisäsi kuitenkin myös rasvan muodostusta.

Tämän tutkimuksen tulokset osoittivat, että verrattaessa täyttävyydeltään toisistaan poikkeavilla rehuilla kasvatettujen lihanautojen kasvua, elopainon lisäys on huono kasvun mitta. Täyttävillä rehuilla ruokittaessa suhteellisesti suurempi osa kasvusta on ruoansulatuskanavan sisältöä kuin väkevillä rehuilla ruokittaessa. Siksi kasvua ja rehuhyötysuhdetta koskevat vertailut tulisikin tehdä ruhotuotokseen perustuen.

Lisäksi tulokset antoivat viitteitä siitä, että käytössä oleva nettoenergiaan perustuva rehuarvojärjestelmä yliarvioi văkirehun todellista rehuarvoa karkearehuihin nähden. 